\title{
New mechanism for reduction catalysis by metal oxo: Hydrosilation of organic carbonyl groups catalyzed by a rhenium(v) oxo complex
}

Elon A. Ison, Evan R. Trivedi, Rex A. Corbin, and Mahdi M. Abu-Omar* Brown Laboratory, Department of Chemistry, Purdue University, 560 Oval Drive, West Lafayette, IN 47907

\section{Supporting Information}

Materials and Methods. Reactions were performed in a nitrogen-filled glovebox or open to the environment as stated. Solvents were degassed, and purified with a solvent purification system developed by Anhydrous Engineering INC. prior to use. Trityl tetra(pentaflourophenyl) borate was purchased from Strem Chemicals and used as received. Organosilanes, were purchased from Gelest or Aldrich and used as received. The oxo- $\operatorname{Re}(\mathrm{V})$ catalyst, $\left[\operatorname{Re}(\mathrm{O})(\mathrm{hoz})_{2}\right][\mathrm{TFPB}]$ (hoz $=2$ - (2'-hydroxyphenyl) - 2 oxazoline(-), TFPB = tetrakis pentaflourophenyl borate), $\mathbf{1}$, and the oxo- $\operatorname{Re}(\mathrm{V})$ chloride, $\mathrm{Re}(\mathrm{O})(\mathrm{hoz})_{2} \mathrm{Cl}$, were synthesized according to published procedures. ${ }^{1,2}$ NMR spectra were recorded on Varian Inova300 instruments. Mass spectrometry was performed by the Purdue University Campus Wide Mass Spectrometry Center using a Hewlett Packard Engine mass spectrometer (GC/MS).

General Procedure for Kinetic Studies $\left(\mathbf{C D}_{2} \mathbf{C l}_{2}\right)$. Stock solutions of $\mathbf{1}(16.4 \mathrm{mM})$ were prepared in $\mathrm{CD}_{2} \mathrm{Cl}_{2}$ in a nitrogen-filled glove box. A re-sealable NMR tube was filled with $1.0 \mathrm{~mL}$ of $\mathrm{CD}_{2} \mathrm{Cl}_{2}, 84 \mu \mathrm{L}(0.64 \mathrm{M})$ of benzaldehyde, $75 \mu \mathrm{L}(0.95 \mathrm{mM})$ of the catalyst stock solution and $10 \mathrm{mg}$ of $\mathrm{Ph}_{3} \mathrm{CH}(31.7 \mathrm{mM})$ (internal standard). The NMR tube was sealed and removed from the glove box. Prior to commencing the catalysis, $\mathrm{Et}_{3} \mathrm{SiH}$ was added, the solution was vigorously shaken, and the tube placed in the NMR 
probe. The progress of the reaction was monitored by integrating the methylene protons of the product $\mathrm{PhCH}_{2} \mathrm{OSiEt}_{3}$ relative to $\mathrm{Ph}_{3} \mathrm{CH}$ with respect to time. The data was analyzed using the Kaleidograph ${ }^{\circledR}$ software package. The observed rate constants $k_{\psi}$ were obtained from nonlinear least squares fitting of $\mathrm{P}_{\mathrm{t}}$ to:

$[\mathrm{P}]_{\mathrm{t}}=[\mathrm{A}]_{0}\left(1-\exp \left(-k_{\psi} \mathrm{t}\right)\right)$

General Procedure for Kinetic Studies $\left(\mathbf{C D}_{3} \mathbf{C N}\right)$. Reactions were performed similar to the $\mathrm{CD}_{2} \mathrm{Cl}_{2}$ reactions but with higher catalyst concentrations (1 mol\%). Data was analyzed using the initial rate method and observed rate constants were obtained from the linear portion of the concentration time curve during the first half life.

Measurement of Deuterium Kinetic Isotope Effect. Benzaldehyde $(16.8 \mu \mathrm{L}$, $0.17 \mathrm{mmol}$ ) was added to a dry NMR tube in a nitrogen filled glove-box. Complex $\mathbf{1}$, (150 $\mu \mathrm{L}$ of a $16.4 \mathrm{mM}$ stock solution) was added; the NMR tube was sealed and removed from the glove-box. Equimolar amounts of $\mathrm{Et}_{3} \mathrm{SiH}$ and $\mathrm{Et}_{3} \mathrm{SiD}(265 \mu \mathrm{l}, 1.7 \mathrm{mmol})$ were then added and the NMR tube was shaken vigorously and the ${ }^{1} \mathrm{H}$ NMR spectrum obtained after 15 minutes. A mixture of products $\mathrm{PhCH}_{2}\left(\mathrm{OSiPh}_{3}\right)$ and $\mathrm{PhCHD}\left(\mathrm{OSiPh}_{3}\right)$ was observed, and the relative ratio of the two species was found to be $1.3: 1$, respectively, by integration, corresponding to a kinetic isotope effect $k_{H} / k_{D}=1.3$.

Stopped-Flow Experiments. The flow circuit was flushed with dry, oxygen-free $\mathrm{CH}_{2} \mathrm{Cl}_{2}$ before the reagent solutions were loaded. One reservoir syringe was filled with $\left[\mathrm{Ph}_{3} \mathrm{C}^{+}\right]\left[\mathrm{B}\left(\mathrm{C}_{6} \mathrm{~F}_{5}\right)_{4}^{-}\right](0.025 \mathrm{mM})$ solution and the other with a solution of the Re hydride, 3, or $\mathrm{Et}_{3} \mathrm{SiH}$. The temperature of the solutions was controlled by a thermostated temperature bath. The two drive syringes were flushed with the solutions twice before collecting data. The rate of disappearance of the trityl signal at $450 \mathrm{~nm}$ with respect to 
time was recorded. The observed rate constants $\left(k_{\psi}\right)$ were obtained from nonlinear least squares fitting of $A_{t}$ to:

$\left[\mathrm{A}_{\mathrm{t}}\right]=\Delta \mathrm{A} \exp \left(-k_{\psi} \mathrm{t}\right)+\mathrm{A}_{\infty}$ where $\Delta \mathrm{A}=\mathrm{A}_{0}-\mathrm{A}_{\infty}$.

Despite using dried $\mathrm{CH}_{2} \mathrm{Cl}_{2}$, plots of [3] versus time are linear with an intercept $\mathrm{k}_{2}=10 \times 10^{-3} \mathrm{~s}^{-1}$ (3) (Fig. S4). This is attributed to negligible side decomposition of the trityl cation in the stopped-flow analyzer due to small adventitious moisture. Activation parameters for the reaction of $\left[\mathrm{Ph}_{3}{ }^{+}\right]\left[\mathrm{B}\left(\mathrm{C}_{6} \mathrm{~F}_{5}\right)_{4}{ }^{-}\right]$and 3 were evaluated from rate measurements over the temperature range 290 - 305 K (Fig. S6).

Synthesis of $\mathbf{R e O}(\mathbf{h o z})_{2} \mathbf{H}, 3$. To a green suspension of $2(1.00 \mathrm{~g}, 1.77 \mathrm{mmol})$ in acetonitrile was added $\mathrm{Bu}_{3} \mathrm{SnH}(1.0 \mathrm{~mL}, 3.79 \mathrm{mmol}, 2.1$ equivs $)$. The suspension was allowed to stir overnight and then the green powder was filtered and washed several times with pentane to yield $3(0.78 \mathrm{~g}, 84 \%$ yield $) .{ }^{1} \mathrm{H}$ NMR $\left(300 \mathrm{MHz}, \mathrm{CD}_{2} \mathrm{Cl}_{2}\right): \delta 7.93$ $(\mathrm{dd}, \mathrm{J}=8.2,1.1 \mathrm{~Hz}, 1 \mathrm{H}), 7.69(\mathrm{dd}, \mathrm{J}=8.2,1.8 \mathrm{~Hz}, 1 \mathrm{H}), 7.46(\mathrm{td}, \mathrm{J}=7.01 .8 \mathrm{~Hz}, 1 \mathrm{H})$, 7.24 (td, $\mathrm{J}=8.8,1.7 \mathrm{~Hz}, 1 \mathrm{H}$ ), 6.99-6.74 (overlapping, 4H), 5.32- 4.01 (overlapping, 8H),
1.53
$(\mathrm{S}$,
$1 \mathrm{H})$;
${ }^{13}$ CNMR
$(300 \mathrm{MHz}$,
$\left.\mathrm{CD}_{2} \mathrm{Cl}_{2}\right)$ :

$\delta 175.5,172.1,179.7,168.5,137.0,135.5,130.0,128.1,122.5,120.0,117.1,116.9,111.6$ 75.3, 71.1, 70.5, 69.1, 59.5. Elemental analysis, Calc. For: $\mathrm{C}_{18} \mathrm{H}_{17} \mathrm{~N}_{2} \mathrm{O}_{5} \mathrm{Re}, \mathrm{C}, 40.98, \mathrm{H}$, 3.25, N, 5.31; Found C, 40.83, H, 3.22, N, 5.38.

Hydrosilation of acetophenone in $\mathbf{C H}_{2} \mathbf{C l}_{2}$. To a $25 \mathrm{~mL}$ round-bottom flask with a magnetic stir bar was added $\operatorname{Re}(\mathrm{O})(\mathrm{hoz})_{2}(\mathrm{TFPB})$ (catalyst) $(0.0103 \mathrm{~g}, 0.009 \mathrm{mmol}, 0.1$ $\mathrm{mol} \%$ ) in $\mathrm{CH}_{2} \mathrm{Cl}_{2}(2.0 \mathrm{~mL})$. Addition of acetophenone (1 mL, $8.57 \mathrm{mmol}, 1$ equiv.) was followed by the addition of triethylsilane $(2.05 \mathrm{~mL}, 12.8 \mathrm{mmol}, 1.5$ equivs $)$. The resulting solution was stirred for three hours. Solvent was removed in vacuo and the 
reaction mixture was subsequently extracted into pentane, removing the catalyst. Pentane was removed in vacuo and the resulting oil was vacuum distilled to obtain triethyl(1phenylethoxy)silane (1.736 g, 86\% yield).

Hydrosilation of 2-butanone without solvent. To a $25 \mathrm{~mL}$ round-bottom flask with a magnetic stir bar was added $\operatorname{Re}(\mathrm{O})(\mathrm{hoz})_{2}(\mathrm{TFPB})(0.0135 \mathrm{~g}, 0.0111 \mathrm{mmol}, 0.1 \mathrm{~mol} \%)$ and 2-butanone (1.0 mL, $11.2 \mathrm{mmol}, 1$ equiv.). To this solution was added triethylsilane (2.67 mL, $16.7 \mathrm{mmol}, 1.5$ equiv), and the resulting brown oil was stirred for $12 \mathrm{~h}$. Over the course of the reaction a dark precipitate slowly formed. The reaction mixture was subsequently extracted into pentane, removing the catalyst as a green precipitate. Solvent was removed in vacuo and the resulting oil was vacuum distilled to obtain triethyl(secbutoxy)silane (1.493 $\mathrm{g}, 71 \%$ yield).

Triethyl(1-phenylethoxy)silane. ${ }^{1} \mathrm{H}$ NMR $\left(300 \mathrm{MHz}, \mathrm{CDCl}_{3}\right): \delta 7.45(\mathrm{t}, \mathrm{J}=6.9 \mathrm{~Hz}$, 2H), $7.40(\mathrm{~d}, \mathrm{~J}=7.8 \mathrm{~Hz}, 2 \mathrm{H}), 7.32(\mathrm{t}, \mathrm{J}=7.0 \mathrm{~Hz}, 1 \mathrm{H}), 4.99(\mathrm{q}, \mathrm{J}=6.3 \mathrm{~Hz}, 1 \mathrm{H}), 1.56(\mathrm{~d}, \mathrm{~J}$ $=6.4 \mathrm{~Hz}, 3 \mathrm{H}), 1.05(\mathrm{t}, \mathrm{J}=7.8 \mathrm{~Hz}, 9 \mathrm{H}), 0.70(\mathrm{q}, \mathrm{J}=7.6 \mathrm{~Hz}, 6 \mathrm{H}) ; \mathrm{GCMS}: \mathrm{m} / \mathrm{z} 236$

Triethyl(sec-butoxy)silane. ${ }^{1} \mathrm{H}$ NMR $\left(300 \mathrm{MHz}, \mathrm{CDCl}_{3}\right): \delta 3.70(\mathrm{~m}, \mathrm{~J}=6.2 \mathrm{~Hz}, 1 \mathrm{H})$, $1.43(\mathrm{~m}, \mathrm{~J}=7.3 \mathrm{~Hz}, 2 \mathrm{H}), 1.11(\mathrm{~d}, \mathrm{~J}=6.0 \mathrm{~Hz}, 3 \mathrm{H}), 0.95(\mathrm{t}, \mathrm{J}=7.9 \mathrm{~Hz}, 9 \mathrm{H}), 0.86(\mathrm{t}, \mathrm{J}=7.5$ $\mathrm{Hz}, 3 \mathrm{H}), 0.58(\mathrm{q}, \mathrm{J}=8.1 \mathrm{~Hz}, 6 \mathrm{H}) ; \mathrm{GCMS}: \mathrm{m} / \mathrm{z} 188$

Triethyl(isopropoxy)silane. ${ }^{1} \mathrm{H}$ NMR $\left(300 \mathrm{MHz}, \mathrm{CDCl}_{3}\right): \delta 3.98(\mathrm{~m}, \mathrm{~J}=6.0 \mathrm{~Hz}, 1 \mathrm{H})$, $1.14(\mathrm{~d}, \mathrm{~J}=6.2 \mathrm{~Hz}, 6 \mathrm{H}), 0.95(\mathrm{t}, \mathrm{J}=8.1 \mathrm{~Hz}, 9 \mathrm{H}), 0.58(\mathrm{q}, \mathrm{J}=8.1 \mathrm{~Hz}, 6 \mathrm{H}) ; \mathrm{GCMS}: \mathrm{m} / \mathrm{z}$ 174

Triethyl(1,2-dimethyl $\boldsymbol{n}$-propoxy)silane. ${ }^{1} \mathrm{H}$ NMR $\left(300 \mathrm{MHz}, \mathrm{CDCl}_{3}\right): \delta 3.57(\mathrm{~m}, \mathrm{~J}=$ $5.9 \mathrm{~Hz}, 1 \mathrm{H}), 1.59(\mathrm{~m}, \mathrm{~J}=5.6 \mathrm{~Hz}, 1 \mathrm{H}), 1.08(\mathrm{~d}, \mathrm{~J}=6.2 \mathrm{~Hz}, 3 \mathrm{H}), 0.97(\mathrm{t}, \mathrm{J}=8.1 \mathrm{~Hz}, 9 \mathrm{H})$, 
$0.88(\mathrm{~d}, \mathrm{~J}=2.5 \mathrm{~Hz}, 3 \mathrm{H}), 0.86(\mathrm{~d}, \mathrm{~J}=2.63 \mathrm{~Hz}, 3 \mathrm{H}), 0.60(\mathrm{q}, \mathrm{J}=7.9 \mathrm{~Hz}, 6 \mathrm{H}) ; \mathrm{GCMS}: \mathrm{m} / \mathrm{z}$ 202

Triethyl(1-ethyl $\boldsymbol{n}$-propoxy)silane. ${ }^{1} \mathrm{H}$ NMR (300 MHz, $\left.\mathrm{CDCl}_{3}\right): \delta 3.53(\mathrm{~m}, \mathrm{~J}=5.9 \mathrm{~Hz}$, 1H), $1.46(\mathrm{~m}, \mathrm{~J}=7.3 \mathrm{~Hz}, 4 \mathrm{H}), 0.98(\mathrm{t}, \mathrm{J}=7.9 \mathrm{~Hz}, 9 \mathrm{H}), 0.88(\mathrm{t}, \mathrm{J}=7.6 \mathrm{~Hz}, 6 \mathrm{H}), 0.61$ (q, J $=7.9 \mathrm{~Hz}, 6 \mathrm{H}) ; \mathrm{GCMS}: \mathrm{m} / \mathrm{z} 202$

Triethyl(benzyloxy)silane. ${ }^{1} \mathrm{H}$ NMR $\left(300 \mathrm{MHz}, \mathrm{CDCl}_{3}\right): \delta 7.34-7.48(\mathrm{~m}, \mathrm{Ar}, 5 \mathrm{H}), 4.86$ (s, 2H), $1.12(\mathrm{t}, \mathrm{J}=7.9 \mathrm{~Hz}, 9 \mathrm{H}), 0.79(\mathrm{q}, \mathrm{J}=7.9 \mathrm{~Hz}, 6 \mathrm{H})$; GCMS: m/z 222

\section{References}

1. Ison, E. A.; Corbin, R. A.; Abu-Omar, M. M. J. Am. Chem. Soc. 2005, 127, $11938-$ 11939.

2. Mcpherson, L. D.; Drees, M.; Khan, S. I.; Strassner, T.; Abu-Omar, M. M. Inorg. Chem. 2004, 43(13), 4036-4050. 


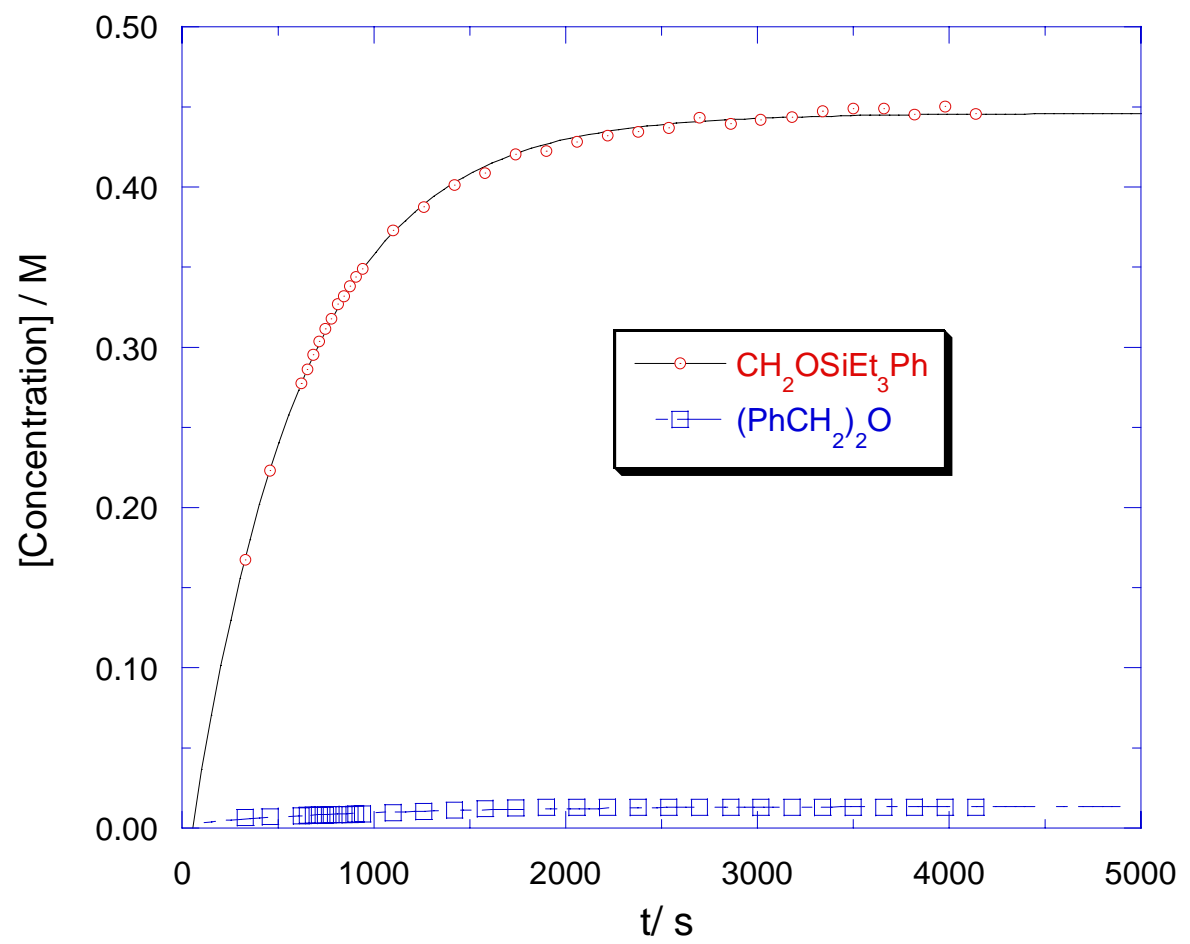

Figure S1. Concentration versus time profile for the hydrosilation of benzaldehyde $(0.642$ M) with $\mathrm{Et}_{3} \mathrm{SiH}(0.642 \mathrm{M})$ and $1(0.952 \mathrm{mM})$ in $\mathrm{CD}_{2} \mathrm{Cl}_{2}$ at $298 \mathrm{~K}$. In addition to the product $\mathrm{PhCH}_{2} \mathrm{OSiEt}_{3}$ (circles) some of the dimeric ether $(<3 \%)$, $\left(\mathrm{Ph}^{\mathrm{C}} \mathrm{CH}_{2}\right)_{2} \mathrm{O}$ was detected (squares). 


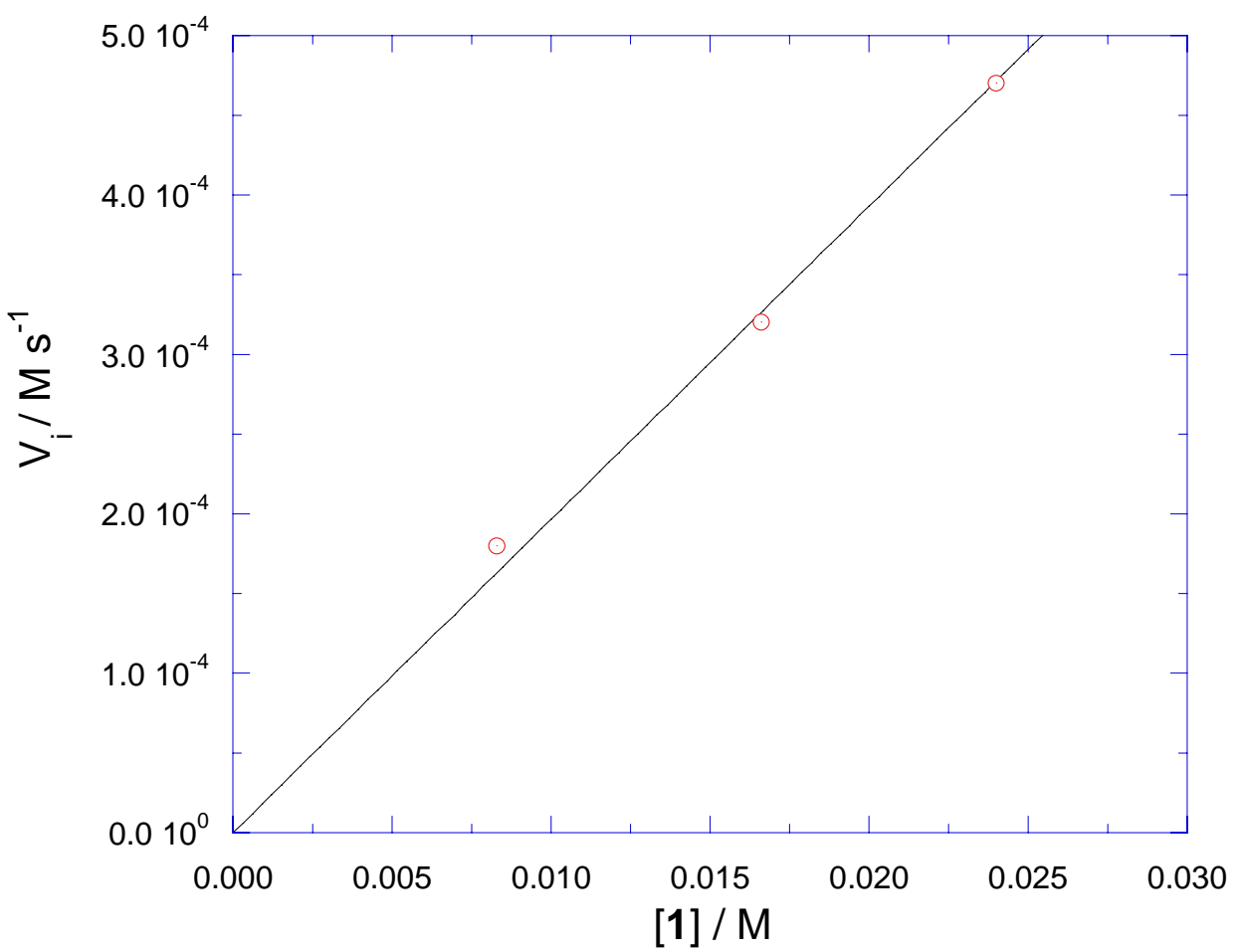

Figure S2. Plot of the initial rate, $\mathrm{V}_{\mathrm{i}}$, versus the concentration of catalyst 1. Rate measurements were carried out in $\mathrm{CD}_{3} \mathrm{CN}$ at $298 \mathrm{~K}$. 


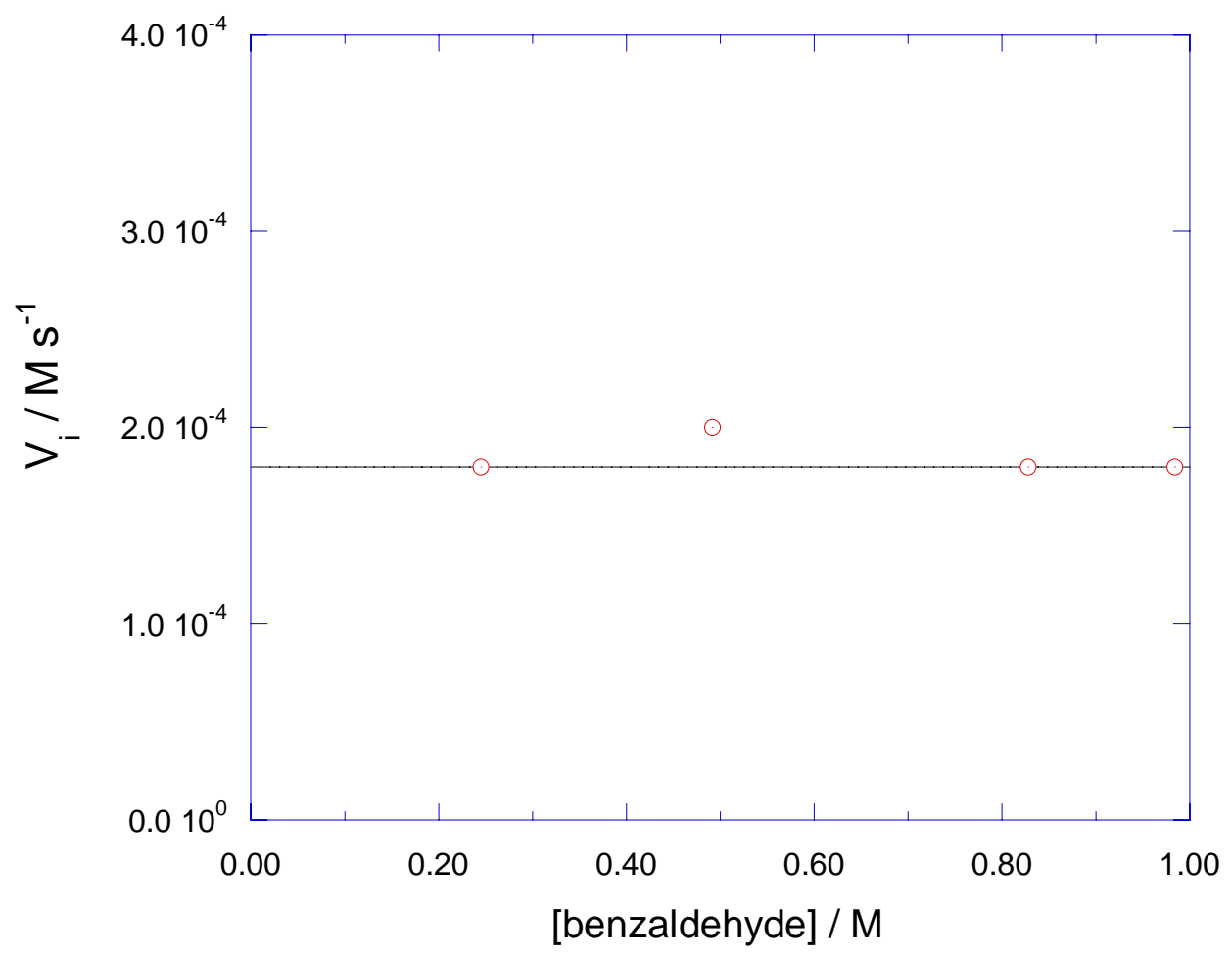

Figure S3. Plot of the initial rate, $\mathrm{V}_{\mathrm{i}}$, versus the concentration of benzaldehyde. Rate measurements were performed in $\mathrm{CD}_{3} \mathrm{CN}$ at $298 \mathrm{~K}$. 


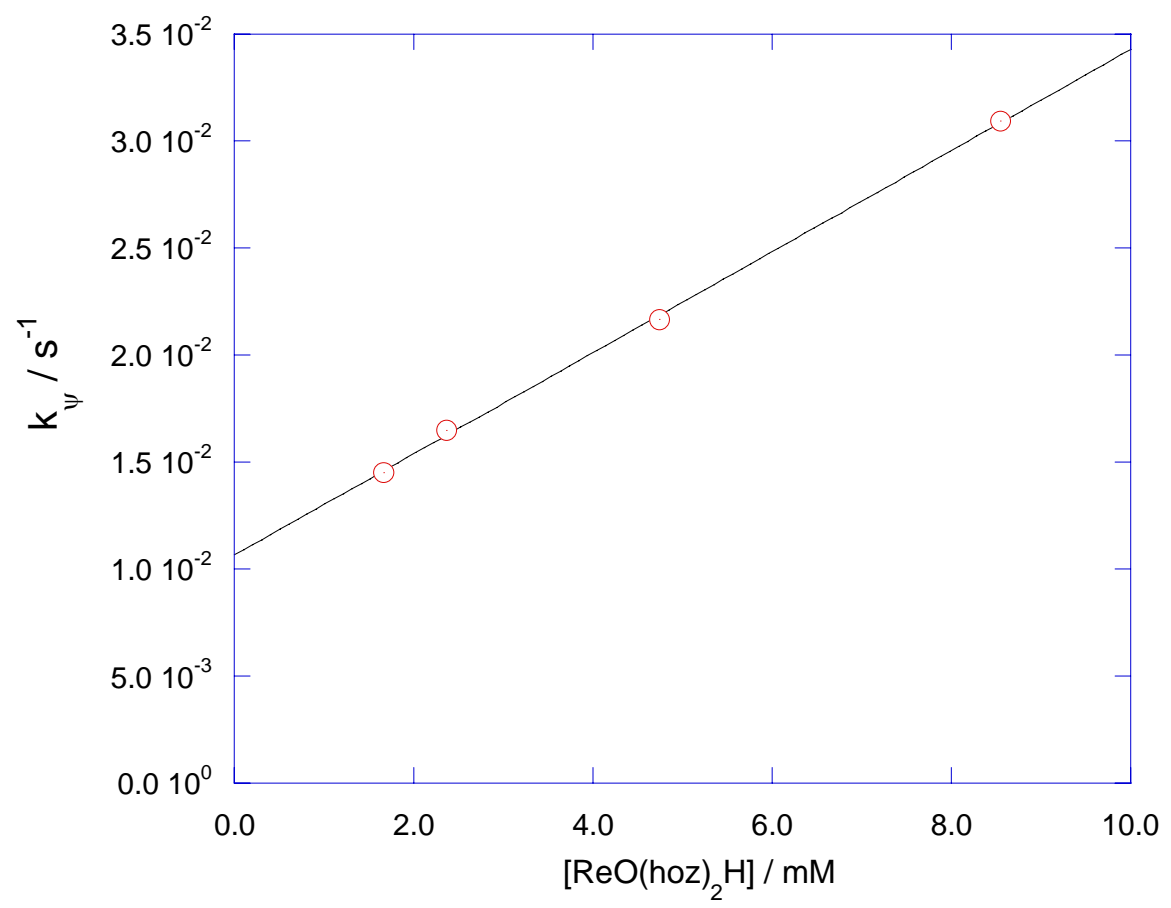

Figure S4. Plot of $\mathrm{k}_{\psi}$ versus $\left[\mathrm{Re}(\mathrm{O})(\mathrm{hoz})_{2}(\mathrm{H})\right]$ in $\mathrm{CH}_{2} \mathrm{Cl}_{2}$ at $295 \mathrm{~K}$. Data was acquired in $\mathrm{CH}_{2} \mathrm{Cl}_{2}$ at $295 \mathrm{~K}$ following the disappearance of $\left[\mathrm{Ph}_{3} \mathrm{C}^{+}\right]\left[\mathrm{B}\left(\mathrm{C}_{6} \mathrm{~F}_{5}\right)_{4}{ }^{-}\right]$at $450 \mathrm{~nm} . k_{\mathrm{Re}-\mathrm{H}}=$ $2.40 \pm .05 \mathrm{M}^{-1} \mathrm{~s}^{-1}$ and an intercept $\mathrm{k}_{2}=(1.10 \pm .02) \times 10^{-2} \mathrm{~s}^{-1}$. 


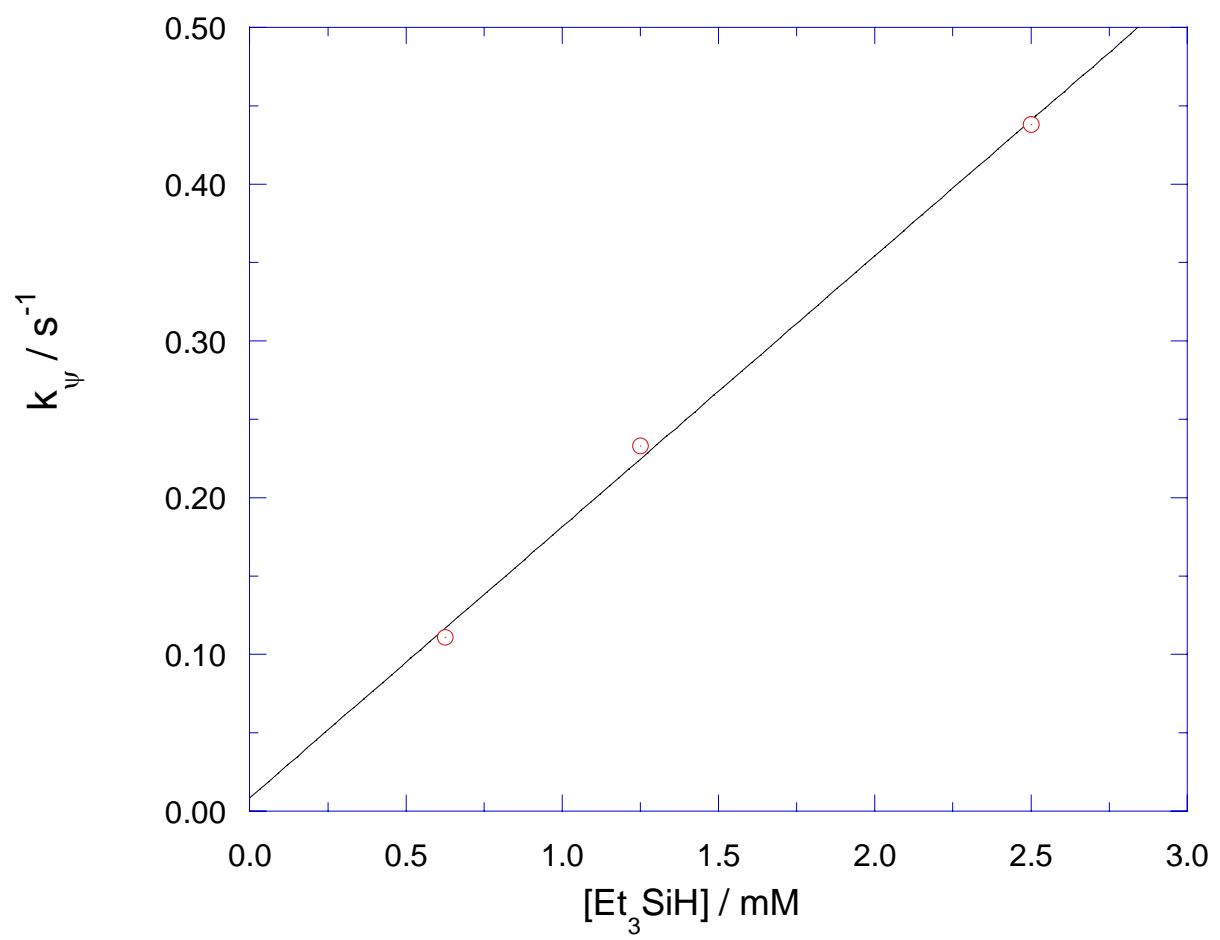

Figure S5. Plot of $\mathrm{k}_{\psi}$ versus [ $\mathrm{Et}_{3} \mathrm{SiH}$ ]. Data was acquired in $\mathrm{CH}_{2} \mathrm{Cl}_{2}$ at $295 \mathrm{~K}$ following the disappearance of $\left[\mathrm{Ph}_{3} \mathrm{C}^{+}\right]\left[\mathrm{B}\left(\mathrm{C}_{6} \mathrm{~F}_{5}\right)_{4}{ }^{-}\right]$at $450 \mathrm{~nm}$. 


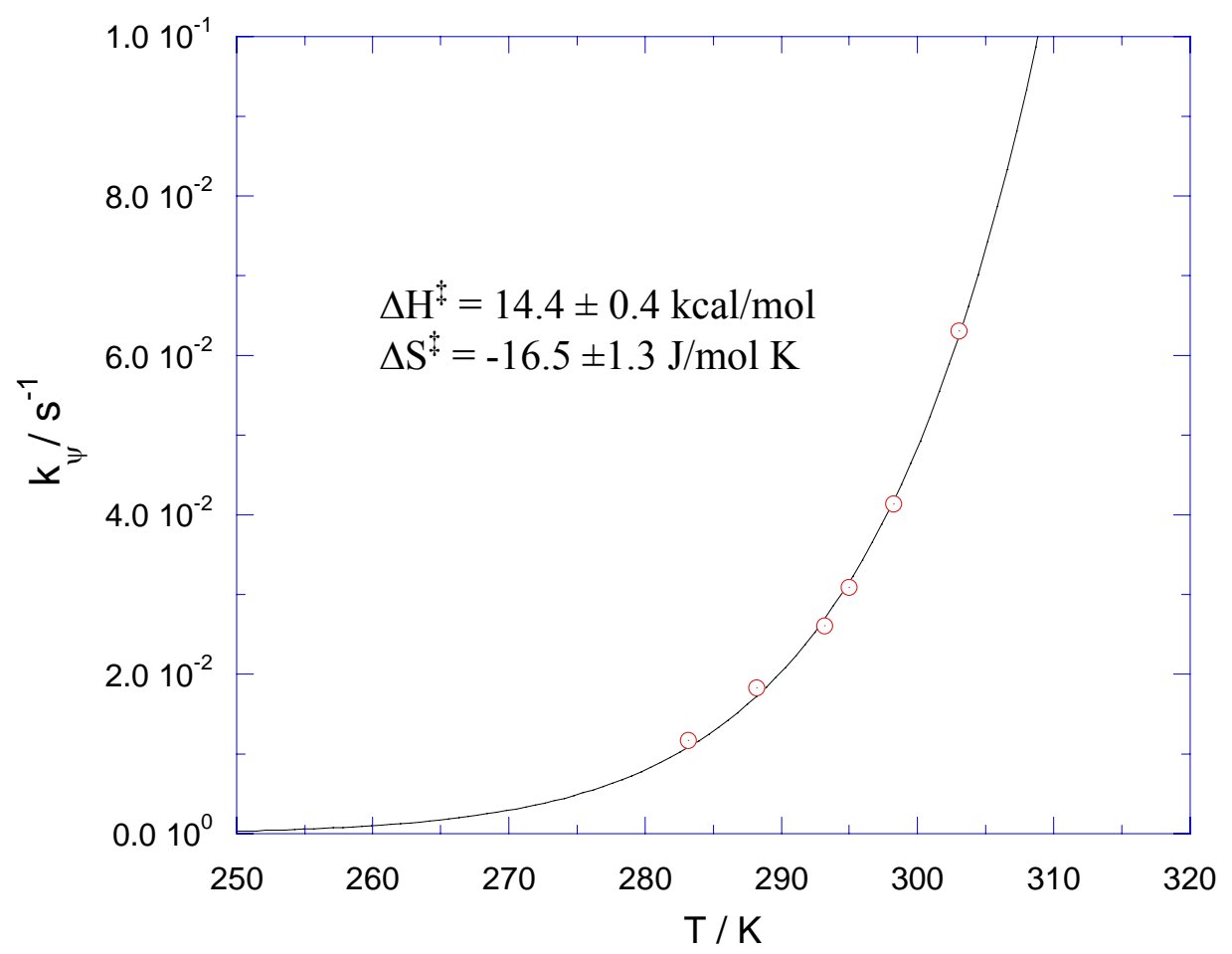

Figure S6. Eyring plot for the reaction of $\left[\mathrm{Ph}_{3} \mathrm{C}^{+}\right]\left[\mathrm{B}\left(\mathrm{C}_{6} \mathrm{~F}_{5}\right)_{4}\right](0.081 \mathrm{mM})$ with $\operatorname{Re}(\mathrm{O})(\mathrm{hoz})_{2}(\mathrm{H})(7.81 \mathrm{mM})$. Data was acquired at $450 \mathrm{~nm}$ and was fitted to the Eyring equation: $k=\frac{k_{b} \mathrm{~T}}{\mathrm{~h}} \exp \left(\frac{-\Delta \mathrm{H}^{\ddagger}}{\mathrm{RT}}+\frac{\Delta \mathrm{S}^{\ddagger}}{\mathrm{R}}\right)$. Reported errors are from the non-linear fitting of the kinetic data to the Eyring equation shown above. 